Pleione 12(1): 81 - 84. 2018.

ISSN: 0973-9467

(c) East Himalayan Society for Spermatophyte Taxonomy

doi:10.26679/Pleione.12.1.2018.081-084

\title{
Taxonomic Status of Saussurea costus (Falc.) Lipsch. (Asteraceae: Cardueae): a critically endangered species from Himalaya, India
}

\author{
Shruti Kasana, Mayank D. Dwivedi and P. L. Uniyal ${ }^{1}$ \\ Department of Botany, University of Delhi, Delhi-110007, India \\ ${ }^{1}$ Corresponding author, e-mail: uniyalpl@rediffmail.com
}

[Received 15.06.2018; Revised \& accepted 18.06.2018; Published 30.06.2018]

\begin{abstract}
The taxonomic status of Saussurea costus (Falc.) Lipsch. (Asteraceae: Cardueae) is discussed along with emphasis on alternative names under genera like Aucklandia Falc., Dolomiaea DC. and Frolovia (DC.) Lipsch. It is widely used for its medicinal properties and listed in Appendix I of CITES as critically endangered species. The present communication will help to eliminate prevailing confusion among taxonomists, conservationists, herbal drug dealers and pharmaceutical industry. Brief account of the genus Saussurea along with detailed history of the species is provided.
\end{abstract}

Key words: Aucklandia, Dolomiaea, Frolovia, Nomenclature

\section{INTRODUCTION}

Saussurea DC. (Asteraceae: Cardueae) includes approximately 400 species distributed mainly in cool temperate (holarctic and arctic) regions of the world (Lipschitz 1979; Raab-Straube 2003; Kita et al.2004; Butola \& Samant 2010). In India, the genus is represented by c. 62 species (Hajra 1988; Hajra et al., 1995). The genus shows distribution in a wide range of habitats from temperate to alpine zones of Himalaya, lowland, stony places, open slopes, forest clearings and even in wastelands. Majority of species are found in areas with altitude higher than $1000 \mathrm{~m}$ above sea level.Sino-Himalayan and Central Asian regions show maximum number of species and greatest diversity of the genus (Haffner 2000; Fujikawa \& Ohba 2003). It has its center of diversity in Asia (Lipschitz 1979), with possibly only one secondary radiation in Europe and America (Dickore 2001). China comprises maximum diversity of species with c. 289 species, out of which 191 have been reported to be endemics(Raab-Straube 2003; Shi et al. 2011). Lipschitz (1979) in his infrageneric classification of Saussurea recognized six subgenera and twenty sections.

Saussurea costus (Falc.) Lipsch., commonly known as Costus or Kuth, belongs to subgenus Frolovia (DC.) Lipsch. and is distributed in Himalayan region of India (Himachal Pradesh, Jammu \& Kashmir, Uttarakhand) China (cultivated) and Pakistan (wild) (Hajra 1988; Pandey et al. 2006, Shi et al. 2011). It was originally described by Falconer (1841) as Aucklandia costus, in Annals and Magazine of Natural History, under a new monotypic genus Aucklandia in the honor of Lord Auckland, based on his own collection from Kashmir. While describing the genus, Falconer stated that it is related to the genus Saussurea. In 1843, Joseph Decaisne (Voy. Inde [Jacquemont] 4(Bot.): 96, t. 104) described it as Aplotaxis lappa based on Jacquemont's collection from Kashmir. Carl Heinrich Schultz ("Bipontinus") in 1847 transferred most of the species from genus Aplotaxis to Saussurea and treated 
Aplotaxis lappa Decne. as a synonym of Saussurea lappa Sch. Bip. In 1891, Kuntze used Theodorea Cass. as the correct name of this genus and reduced Saussurea DC. to its synonymy as Salisbury (1807) had already named a genus of Liliaceae as Saussurea. Now, Theodorea is a subgenus under Saussurea, named in the honor of Theodore de Saussure. Hence, Aucklandia costus Falc. was changed to Theodorea costus Kuntze. Later, Saussurea DC. was conserved against Saussurea Salisbury (1807). This leads to acceptance of Saussurea costus as the correct name instead of Theodorea costus in 1964. Aucklandia costus is basionym of Saussurea costus. In the Flora of China (Shi et al. 2011), it is accepted under the monotypic genus Aucklandia Falc.

Molecular systematic studies using nrDNA (ITS) and cpDNA (trnL-F, psbA-trnH) with multiple accessions and sampling from Pan-Himalaya have revealed that the accessions of Saussurea costus collected from different localities in Jammu \& Kashmir and Uttarakhand, India) along with accessions from China recovers the species as monophyletic and its placement in the Dolomiaea clade (Wang et al., 2007). All these data support the placement of $S$. costus in the genus Dolomiaea DC.

Saussurea costus is a widely used name in the taxonomic and ayurvedic literature of India and China (Pandey et al. 2007; Butola \& Samant 2010). The species is native to North-West India and North-East Pakistan, but widely cultivated in China and Nepal for its medicinal properties (Hajra, 1988; Hajra et al. 1995; Kuniyal et al. 2005; Butola \& Samant 2010; Shi et al.2011). The roots of this plant are used for the treatment of various ailments like rheumatism, ulcer, leprosy and dysentery and are traded in international markets for use as drugs (Pandey et al. 2007). The presence of strong aromatic odour in the roots of this plant makes it highly useful in perfume and incense industry. In tribal areas, the roots are also used as insecticides to protect clothes from damage (Mittre, 1981). The species is also known to possess important bioactive molecules like Costunolide and Cynaropicrin, which makes it a highly useful plant (Pandey et al.2007). Due to the high demand of this species in pharmaceutical industry, it has been highly over harvested from wild and is now considered as critically endangered and is enlisted in Appendix I ofCITES. The high economic importance of this species and common name Costus or Kuth make it necessary to discuss its taxonomic status.

Under such a taxonomic background, the species is to be treated as:

Saussurea costus (Falc.) Lipsch., Bot. Zhurn. (Moscow \& Leningrad) xlix. 131 (1964). 131. 1964. Aucklandia costus Falc., Ann. Mag. Nat. Hist. 6: 475. 1841; Theodorea costus Kuntze, Revis. Gen. P1. 1: 368 368. 1891. Aucklandia lappa Decne, Iconographia Cormophytorum Sinicorum 4: “643, f. 6700”. 1875.

Specimens examined: INDIA, Himachal Pradesh, Chitkul, 17 Aug. 1973, K.P. Janardhanan 52774 (BSD); Lahul, Chhatru, 5 Sept. 1961, N.C. Nair 16669 (BSD); Lahul, Koksar, 2 Aug. 1971, U.C. Bhattacharyya 44987 (BSD); Lahul, Koksar, 5 Sept. 1985, P.K. Hajra 76995 (BSD); Lahul, Kyelong, 14 July 1941, N.L. Bor 9934 (DD); Lahul, Sissu, 26 June 1958, M.A. Rau 5919 (BSD); Lahul, Sissu, 5 July 1938, N.L. Bor 12320 (DD); Nichar, 28 May 1962, N.C. Nair 22065 (BSD). Kashmir, Jahlma, Nalda-Jasrath Reserve, Pattan valley, 10 June 1958, SP Sethi (DD); JojuBasa to Guru Kot, 22 Sept. 1838, H. Falconer s.n. (DD); Kashmir, H. Falconers.n. (K); In montibus supra Pendjegam, V. Jacquemont 900 (P); In sylvisexub. mont.Vestervonne "inter" Cachemir, V. Jacquemont 727 (P); Keyan forest, Kamah basin, Kishanganga valley, 12 July 2006, Keshavanand 207 (DD); KilshaiBala in Tilal, Kishanganga valley, 25 Sept. 2009, Keshavanand 1576 (DD); Kunpathri, below masitnagar in Tilal, Kishanganga, 13 Sept. 2009, Keshavanand 1515 (DD); Rambani, 27 June 1925, Sher Singh 
(DD); Shakhara stream, Jagran basin, 5 Aug. 2006, Keshavanand 355 (DD); Sonmarg, Sind valley, 5 Aug.1891, G.A. Gamm (DD); Thajwas mountains, 18 June 1959, T.A. Rau 9563 (BSD); Western Kashmir, Jacquemont, V. 1142 (K); Uttarakhand, Chamoli district, North of Bumpa, 6 Sept.1975, B.D. Naithani 56102 (BSD); Dronagiri, P.K. Hajra \& Bipin Badoli 87551 (BSD); Garhwal, Buhna, 15 June 1959, M.A. Rau 10209 (BSD).

\section{Acknowledgements}

Shruti Kasana is thankful to the Council of Scientific and Industrial Research, India for the award of Junior Research Fellowship. Authors are thankful to Prof. Arun K. Pandey, University of Delhi and Dr L.B. Chaudhary, NBRI, Lucknow for critically going through the manuscript. Thanks are due to Joint Directors of DD and BSD for the permission to consult the herbarium specimens.

\section{CONCLUSIONS}

Replacing this well-established name with any other less known name, especially under a different genus, will create confusion to taxonomists, conservationists, herbal drug dealers and pharmaceuticals. Considering the fact that $S$. costus is widely used for its medicinal value and is also listed as critically endangered, changing its name is not recommended.

\section{LITERATURE CITED}

Butola, J.S. \& Samant, S.S. 2010.Saussurea species in Indian Himalayan Region: Diversity, distribution and indigenous uses. Intn. J. Plant Biol. 1 (e9): 43 - 51.

Candolle, A.P. de 1810. Observations sur les plantes Composées ou Syngenèses. Premier mémoire. Sur les Composées et les Cinarocéphales en général. Ann. Mus. Hist. Nat. 16: $135-158$.

Decaisne, J. 1843. Voyage dans l'Inde, 4: 96, 104. M. Guizot. Paris.

Dickoré, W.B. 2001. Observations of some Saussurea (Compositae - Cardueae) of W Kunlun, Karakorum and W Himalaya. Edinb. J. Bot. 58(1): 15-29.

Falconer, H. 1841. Aucklandia. In: W. Jardine; P.J. Selby; Johnston; David Don \& Richard Taylor (eds.), Annals and Magazine of Natural History; zoology, botany and geology, 6: 475. Taylor and Francis, London.

Fujikawa, K. \& Ohba, H. 2003. A cytological study of Saussurea Subgenus Eriocoryne (Asteraceae) from the Nepal Himalaya. J. Jap. Bot. 78: 135 - 144.

Haffner, E. 2000. On the phylogeny of the subtribe Carduinae (Cardueae, Compositae). Englera. 21: $1-208$.

Hajra, P.K. 1988. Brahmakamal and its allies (Saussurea the genus). Jugal Kishore \& Co., Dehradun, India.

Hajra, P.K. 1995. Tribe Cardueae. In: P.K. Hajra; R.R. Rao; D.K. Singh \& B.P. Uniyal (eds.), Flora of India, Vol. 12. Botanical Survey of India, Calcutta. Pp. 150 - 226.

Kita, Y.; Fujikawa, K.; Ito, M.; Ohba, H. \& Kato, M. 2004. Molecular Phylogenetic analysis and systematic of the genus Saussurea and related genera (Asteraceae: Cardueae). Taxon. 53: $679-6990$.

Kuniyal, C.P.; Rawat, Y.S.; Oinam, S.S.; Kuniyal, J.C. \& Vishvakarma, S.C.R. 2005. Kuth (Saussurea lappa) cultivation in the cold desert environment of the Lahul valley, northwestern Himalaya, India: arising threats and need to revive socio-economic value. Biodiversity and Conservation 14: 1035 - 1045. 
Lipschitz, S.J. 1964. Saussurea. In: Botanicheskii Zhurnal, 49: 131. Moscow \& Leningrad [St. Petersburg]

Lipschitz, S.J. 1979. Rod Saussurea DC.(Asteraceae). Nauka, Leningrad.

McNeill, J.; Barrie, F.R.; Buck, W.R.; Demoulin, V.; Greuter, W.; Hawksworth, D.L.; Herendeen, P.S.; Knapp, S.; Marhold, K.; Prado, J.; Prud'homme van Reine, W.F.; Smith, G.E.; Wiersema, J.H. \& Turland, N.J. (eds.) 2012. International Code of Nomenclature for algae, fungi, and plants (Melbourne Code), adopted by the Eighteenth International Botanical Congress Melbourne, Australia, July 2011. [Regnum Vegetabile no. 154.]Ruggell: A.R.G. GantnerVerlag.

Mittre, V. 1981. Wild plants in Indian folk life a historical perspective. In: Jain, S.K. (ed.), Glimpses of Indian Ethnobotany. Oxford \& IBBH, New Delhi, India. Pp. 37 - 58.

Pandey, M.M.; Rastogi, S. \& Rawat, A.K. 2007. Saussurea costus: Botanical, chemical and pharmacological review of an ayurvedic medicinal plant. J. Ethanopharma. 110: 379 390.

Raab-Straube, E. von 2003. Phylogenetic relationships in Saussurea (Asteraceae: Cardueae) sensu lato, inferred from morphological, ITS and $t r n \mathrm{~L}-t r n \mathrm{~F}$ sequence data with a synopsis of Himalaiella gen. nov., Lipschitzella and Frolovia. Willdenowia. 33: 379 - 402.

Raab-Straube, E. von 2017. Taxonomic revision of Saussurea subgenus Amphilaena (Compositae, Cardueae). ed. 1. BGBM Press, Botanic Garden and Botanical Museum Berlin, Freie Universität Berlin.

Salisbury 1807. Transactions of the Linnaean Society of London, London, 8: 11. London.

Schultz 1847. Saussurea In: Garcke, A. \& Schlechtendal, D.F. L. von (eds.), Linnaea, 19: 331. Berlin.

Shi, Z.; Raab-Straube, E. Von; Greuter, W. \& Martins, L. 2011. Cardueae. In: Wu, Z. Y.; Raven, P. H. \& Hong, D. Y. (eds.), Flora of China, Vol. 20-21 (Asteraceae). Science Press (Beijing) \& Missouri Botanical Garden Press (St. Louis). Pp. 42 - 194.

Wang, Y.J.; Liu, J.Q. \& Miehe, G 2007. Phylogenetic origins of the Himalayan endemic Dolomiaea, Diplazoptilon and Xanthopappus (Asteraceae: Cardueae) based on three DNA fragments. Ann. Bot. (oxford). 99: 311 - 322.

Yuan, Qian \& Bi, Yanchao \& Chen, Yousheng 2015. Diplazoptilon (Asteraceae) is merged with Saussurea based on evidence from morphology and molecular systematics. Phytotaxa. 236. 53. 10.11646/phytotaxa.236.1.4. 